\title{
Model Geographically Weighted Regression dengan Fungsi Pembobot Adaptive dan Fixed Kernel pada Kasus Kematian Ibu di Jawa Timur
}

\author{
Ulfie Safitri ${ }^{1, \text { a) }}$, Luthfatul Amaliana ${ }^{1, \text { b) }}$ \\ ${ }^{1}$ Jurusan Statistika, Fakultas Matematika dan Ilmu Pengetahuan Alam, Universitas Brawijaya, Malang \\ Email: a) ulfiesafitri@ student.ub.ac.id, ${ }^{\text {b) }}$ luthfatul@ub.ac.id
}

\begin{abstract}
Geographically Weighted Regression (GWR) model is a development of multiple linear regression model that can produce local estimators of model parameters for each point or location where the data is observed. The GWR model can be used if the data meet the assumption of spatial heterogeneity caused by differences in data conditions between one location and another. This study aims to determine the best GWR modeling using weighted adaptive kernel or fixed kernel in modeling cases of maternal mortality in East Java in 2018. The data used in this study are maternal mortality data as a response variable and the household behavior healthy clean living, pregnant women visiting with $\mathrm{K} 4$, pregnant women receiving $\mathrm{Fe} 3$ tablets, the deliveries assisted by health workers, and the number of health facilities as predictor variables. Based on the criteria for selecting the best model seen from the smallest AIC value, it can be concluded that the GWR modeling with the adaptive bi-square kernel weighting function is the best model for maternal mortality data. Factors affecting maternal mortality cases based on parameter testing partially are pregnant women visiting with $\mathrm{K} 4$ and the number of health facilities.
\end{abstract}

Keywords: adaptive kernel, fixed kernel, GWR, maternal deaths, spatial heterogeneity

\begin{abstract}
Abstrak
Model Geographically Weighted Regression (GWR) merupakan pengembangan dari model regresi linier berganda yang dapat menghasilkan penduga parameter model yang bersifat lokal untuk setiap titik atau lokasi di mana data diamati. Model GWR dapat digunakan apabila data memenuhi asumsi heterogenitas spasial yang diakibatkan oleh perbedaan kondisi data antara satu lokasi dengan lokasi lain. Penelitian ini bertujuan untuk menentukan model GWR terbaik dengan pembobot adaptive kernel dan fixed kernel pada kasus kematian ibu di Jawa Timur tahun 2018. Data yang digunakan pada penelitian ini adalah data kematian ibu sebagai variabel respon dan rumah tangga berperilaku hidup bersih sehat, kunjungan ibu hamil dengan $\mathrm{K} 4$, ibu hamil mendapat tablet $\mathrm{Fe}$ 3, persalinan yang ditolong tenaga kesehatan, serta jumlah fasilitas kesehatan sebagai variabel prediktor. Berdasarkan kriteria pemilihan model terbaik yang dilihat dari nilai AIC terkecil dapat disimpulkan bahwa model GWR dengan fungsi pembobot adaptive bi-square kernel merupakan model terbaik untuk data kematian ibu. Faktor yang mempengaruhi kasus kematian ibu berdasarkan pengujian parameter secara parsial yaitu kunjungan ibu hamil dengan K4 dan jumlah fasilitas kesehatan.
\end{abstract}

Kata-kata kunci: adaptive kernel, fixed kernel, GWR, kematian ibu, heterogenitas spasial 


\section{PENDAHULUAN}

Analisis regresi merupakan metode statistika yang digunakan untuk memodelkan hubungan antara satu variabel respon dengan satu atau lebih variabel prediktor (Charlton, Fotheringham dan Brunsdon, 2009). Pendugaan parameter regresi dapat dilakukan dengan metode Ordinary Least Square (OLS) di mana asumsi residual yang harus dipenuhi adalah identik (homoskedastisitas), independen (non autokorelasi) dan berdistribusi normal. Perbedaan kondisi lingkungan dan geografis di suatu lokasi dengan lokasi yang lain dapat menyebabkan terjadinya pelanggaran asumsi homoskedastisitas dan non-autokorelasi. Hal tersebut mengindikasikan adanya efek spasial. Model yang sesuai untuk pola hubungan variabel yang memiliki efek spasial adalah regresi spasial (Anselin, 1998). Efek spasial mencakup spatial dependency (kebebasan spasial) dan spatial heterogeneity (keheterogenan spasial) (Anselin dan Getis, 1992). Heterogenitas spasial adalah suatu kondisi pada suatu wilayah yang memiliki perbedaan kondisi antara satu lokasi dengan lokasi yang lain, yang ditinjau dari segi geografis, keadaan sosial-budaya maupun hal lain yang dapat menimbulkan kondisi heterogenitas spasial pada lokasi yang diteliti (Munikah et al., 2014). Geographically Weighted Regression (GWR) merupakan metode statistika yang dapat digunakan untuk mengatasi heterogenitas spasial. Pemodelan GWR menggunakan matriks pembobot yang besarnya tergantung pada kedekatan antar lokasi serta menghasilkan estimasi parameter model yang bersifat lokal untuk setiap lokasi dan berbeda dengan lokasi lainnya (Fotheringham, Brunsdon, dan Charlton, 2002).

Menurut Kementerian Kesehatan (2014), WHO mendefinisikan kematian ibu yaitu kematian yang bukan diakibatkan dari sebuah kecelakan maupun cidera. Kematian ibu merupakan kematian selama kehamilan atau dalam waktu 42 hari setelah berakhirnya kehamilan yang diakibatkan semua sebab yang berkaitan dengan kehamilan dan penanganannya. Upaya peningkatan status kesehatan ibu dan anak termasuk penurunan angka kematian ibu menjadi salah satu prioritas pembangunan nasional yang tercantum di dalam sasaran pokok Rencana Pembangunan Jangka Menengah Tahun 2015-2019. Data Profil Kesehatan Jawa Timur (2018) menunjukkan bahwa angka kematian ibu di Jawa Timur mencapai 91.45 per 100.000 kelahiran hidup pada tahun 2018. Oleh karena itu, kematian ibu di Jawa Timur terus diupayakan untuk turun melalui faktor-faktor yang diduga dapat mempengaruhinya.

Penelitian tentang GWR telah dilakukan oleh beberapa peneliti sebelumnya, namun hanya menggunakan fungsi pembobot sejenis, yakni adaptive saja atau fixed saja. Sedangkan pada penelitian ini pemodelan GWR dilakukan menggunakan dua jenis pembobot fungsi kernel yaitu adaptive kernel dan fixed kernel yang mencakup kernal gaussian, bisquare, dan tricube. Hal ini penting untuk dilakukan agar diperoleh model GWR dengan fungsi pembobot spasial terbaik untuk data kasus kematian ibu di Jawa Timur tahun 2018.

\section{METODOLOGI}

\section{Data}

Data yang digunakan pada penelitian ini adalah data sekunder yang bersumber dari Profil Kesehatan Provinsi Jawa Timur tahun 2018. Penelitian ini melibatkan 38 kota/kabupaten di Provinsi Jawa Timur sebagai unit pengamatan. Adapun variabel respon dan variabel-variabel prediktor yang digunakan pada penelitian ini terangkum dalam TABEL 1.

TABEL 1. Variabel Penelitian

\begin{tabular}{clc}
\hline Variabel & \multicolumn{1}{c}{ Keterangan } & Satuan \\
\hline $\mathrm{Y}$ & Jumlah Kematian Ibu & - \\
$\mathrm{X}_{1}$ & Rumah Tangga ber-Perilaku Hidup Bersih dan Sehat (PHBS) & Persen \\
$\mathrm{X}_{2}$ & Ibu Hamil Mendapat Tablet Fe3 & Persen \\
$\mathrm{X}_{3}$ & Kunjungan pada Ibu Hamil (K4) & Persen \\
$\mathrm{X}_{4}$ & Persalinan oleh Tenaga Kesehatan & Persen \\
$\mathrm{X}_{5}$ & Jumlah Fasilitas Kesehatan & - \\
\hline
\end{tabular}




\section{Metode Penelitian}

Penelitian ini menggunakan dua macam analisis yaitu analisis deskriptif dan analisis inferensial. Analisis deskriptif digunakan untuk mengetahui gambaran secara umum kasus kematian ibu dan faktorfaktor yang diduga berpengaruh. Sedangkan analisis inferensial yang digunakan pada penelitian ini adalah analisis spasial pendekatan titik yaitu Geographically Weighted Regression (GWR).

Tahapan analisis yang diterapkan pada data sebagai berikut.

1. Mempersiapkan data.

2. Melakukan analisis deskriptif.

3. Melakukan uji simultan dan parsial pada model regresi linier berganda

4. Menguji stasioneritas data spasial

5. Menguji asumsi multikolinieritas menggunakan kriteria Variance-Inflation Factor(VIF).

6. Membentuk matriks pembobot $\boldsymbol{W}\left(u_{i}, v_{i}\right)$.

a. Menghitung jarak Euclidean antar lokasi menggunakan koordinat titik $\left(\begin{array}{l}u_{i} \\ v_{i}\end{array}\right)$.

b. Menentukan bandwidth optimum berdasarkan kriteria CV minimum.

7. Menguji heterogenitas spasial menggunakan uji Breusch-Pagan.

8. Melakukan pendugaan parameter model GWR untuk setiap lokasi.

9. Menguji kesesuaian parameter model regresi linier dengan parameter model GWR.

10.Menguji signifikansi parameter GWR secara parsial.

11.Menentukan model terbaik berdasarkan nilai AIC.

12. Interpretasi model GWR.

\section{Analisis Regresi Linier Berganda}

Regresi linier berganda biasanya digunakan untuk menyatakan hubungan linier apabila terdapat lebih dari dua variabel. Pada regresi linier berganda terdapat satu variabel respon (dependent variable), yaitu $\mathrm{Y}$ dan beberapa variabel prediktor (independent variable), yaitu $\mathrm{X}_{1}, \mathrm{X}_{2}, \ldots, \mathrm{X}_{\mathrm{k}}$. Saat ini teknik statistik analisis regresi adalah alat utama yang digunakan untuk memperoleh estimasi (Gujarati, 2004). Persamaan regresi linier berganda secara matematik diekspresikan oleh:

$$
Y_{i}=\beta_{0}+\beta_{1} X_{1 i}+\beta_{2} X_{2 i}+\cdots+\beta_{j} X_{j i}+\varepsilon_{i}
$$

Keterangan:

$Y_{i} \quad$ : variabel respon dari amatan $i=1,2,3, \ldots, n$

$n$ : banyaknya pengamatan

$\beta_{0}:$ intercept

$\beta_{j} \quad$ : parameter regresi prediktor ke- $j$

$X_{j i}$ : variabel prediktor ke- j pada pengamatan ke- $i=1,2,3, \ldots, n$

$\varepsilon_{i} \quad$ : galat pada pengamatan ke- $i$.

\section{Pengujian Parameter Model}

Pengujian parameter dilakukan untuk mengetahui ada atau tidaknya pengaruh variabel bebas terhadap variabel terikat baik secara simultan (bersam-sama) atau parsial (sendiri-sendiri).

a. Uji Simultan

Pengujian simultan dilakukan untuk mengetahui pengaruh variabel bebas secara bersama-sama terhadap variabel terikat. Berikut ini merupakan hipotesis untuk uji simultan.

$$
\begin{aligned}
& H_{0}: \beta_{1}=\beta_{2}=\cdots=\beta_{p-1}=0 \\
& H_{1}: \text { Tidak semua } \beta_{k} \text { sama dengan nol, untuk } k=1,2, \ldots, p-1
\end{aligned}
$$


Statistik Uji:

$$
F=\frac{M S R}{M S E}
$$

Keterangan:

MSR : Rata-rata kuadrat regresi

MSE : Mean Square Error (jumlah kuadrat error)

Kriteria pengambilan keputusan yaitu akan tolak $H_{0}$ ketika statistik uji $F$ lebih besar daripada $F_{\text {tabel }}$ pada derajat bebas $p-1, n-p$ saat tingkat signifikansi $\alpha$. Selain itu, juga bisa digunakan tingkat signifikansi dalam pengambilan keputusan, dimana $H_{0}$ ditolak ketika $p$-value lebih kecil daripada tingkat signifikansi $\alpha$.

b. Uji Parsial

Pengujian parsial dilakukan untuk mengetahui pengaruh variabel bebas secara sendiri-sendiri terhadap variabel terikat. Berikut ini merupakan hipotesis untuk uji parsial.

$H_{0}: \beta_{k}=0$

$H_{1}: \beta_{k} \neq 0$, untuk $k=1,2, \ldots, p-1$

Statistik Uji:

Keterangan:

$$
t=\frac{b_{k}}{s\left(b_{k}\right)}
$$

$b_{k} \quad:$ nilai dugaan parameter $\beta_{k}$

$S\left(b_{k}\right) \quad$ : Standar deviasi nilai dugaan parameter $\beta_{k}$

Geographically Weighted Regression

Model Geographically Weighted Regression (GWR) merupakan pengembangan dari model regresi linier berganda. Model GWR menghasilkan penaksir parameter model yang bersifat lokal untuk setiap titik atau lokasi di mana data tersebut diamati. Model GWR dapat ditulis sebagai berikut (Fotheringham et al., 2002):

Keterangan:

$$
y_{i}=\beta_{0}\left(u_{i}, v_{i}\right)+\sum_{k=1}^{p} \beta_{k}\left(u_{i}, v_{i}\right) x_{i k}+\varepsilon_{i}
$$

y $\quad$ : nilai variabel respon untuk lokasi ke- $i$

$x_{i k} \quad:$ nilai variabel prediktor ke-kpada lokasi pengamatan ke- $, i k=1,2, \ldots, p$

$\beta_{0}\left(u_{i}, v_{i}\right) \quad$ : intersep model GWR

$\beta_{k}\left(u_{i}, v_{i}\right) \quad:$ koefisien regresi variabel prediktor ke- $k$

$\left(u_{i}, v_{i}\right) \quad:$ koordinat letak geografis (lintang, bujur) dari lokasi pengamatan ke- $i$

$\varepsilon_{i}$

: residual pengamatan ke- $i$ yang berdistribusi normal dengan $E(\varepsilon)=0$ dan $V(\varepsilon)=\sigma_{\varepsilon}^{2}$

\section{Uji Asumsi Non Multikolinieritas}

Uji non multikolinearitas bertujuan untuk menguji apakah dalam model regresi ditemukan adanya korelasi linier yang tinggi atau sempurna antara variabel prediktor. Salah satu cara yang dapat digunakan untuk mendeteksi ada atau tidaknya multikolinearitas adalah dengan melihat nilai Variance Inflaction Factor (VIF) dari masing-masing variabel prediktor. Nilai VIF yang lebih besar dari 10 mengindikasikan adanya multikolinieritas yang serius. VIF dapat dihitung melalui persamaan (5).

$$
V I F_{j}=\frac{1}{\left(1-R_{j}^{2}\right)}
$$




\section{Uji Heterogenitas Spasial}

Heterogenitas spasial adalah suatu kondisi apabila satu variabel prediktor yang sama memberikan respon yang tidak sama pada lokasi yang berbeda dalam satu wilayah penelitian (Caraka dan Yasin, 2017). Menurut Anselin (1988), heterogenitas spasial dapat diuji menggunakan statistik uji BreuschPagan.

$H_{0}: \sigma_{1}^{2}=\sigma_{2}^{2}=\cdots=\sigma^{2}$ (tidak terjadi heterogenitas antar wilayah)

$H_{1}$ : paling tidak ada satu $\sigma_{i}^{2} \neq \sigma^{2}$ (terjadi heterogenitas antar wilayah)

Statistik Uji:

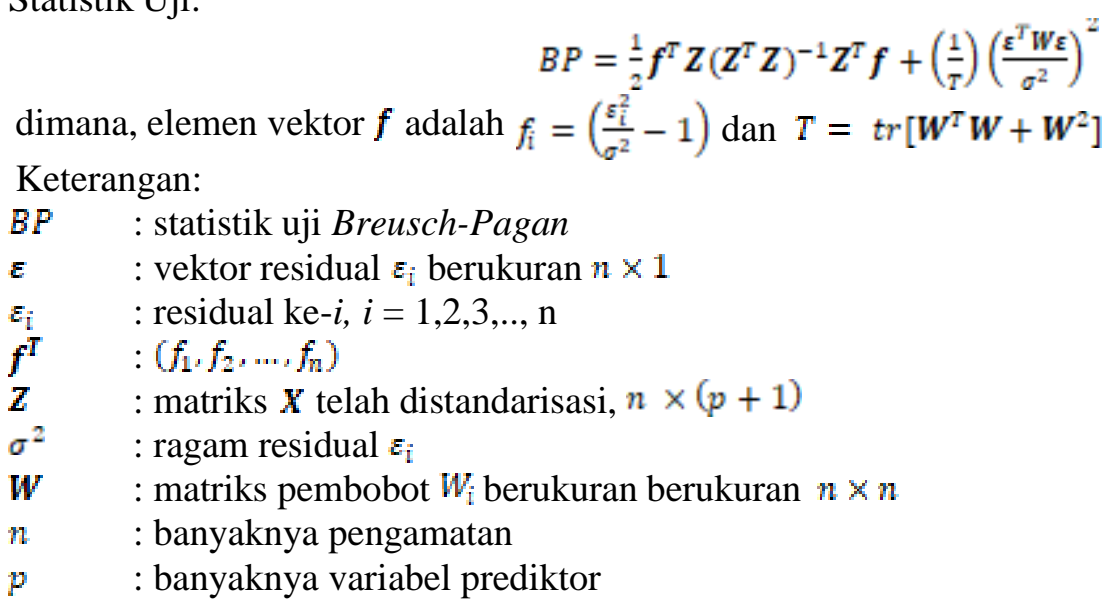

Dalam uji Breusch-Pagan, kriteria pengambilan keputusan akan tolak $H_{0}$ apabila statistik uji $B P>\chi_{\left(\frac{a}{2} p+1\right)}^{2}$

\section{Bandwidth Optimum}

Bandwidth adalah ukuran jarak-peluruhan dalam fungsi pembobotan dan menunjukkan sejauh mana hasil kalibrasi lokal yang dihaluskan (Fotheringham dkk., 2002). Pemilihan bandwidth optimum menjadi sangat penting karena dapat mempengaruhi hasil pendugaan model. Terdapat beberapa metode yang dapat digunakan untuk memilih bandwidth optimum, salah satu metodenya yaitu menggunakan Cross Validation (CV) dengan rumus berikut.

$$
C V(h)=\sum_{i=1}^{n}\left(y_{i}-\hat{y}_{\neq i}(h)\right)^{2}
$$

Keterangan:

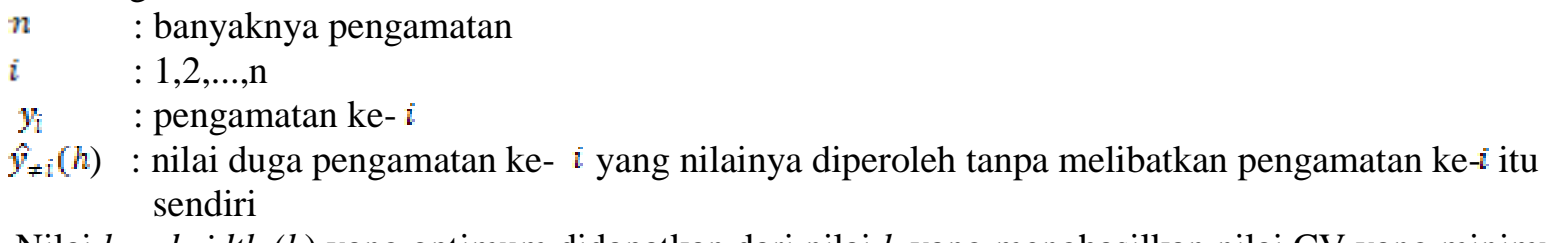

Nilai bandwidth $(h)$ yang optimum didapatkan dari nilai $h$ yang menghasilkan nilai CV yang minimum.

\section{Fungsi Pembobot GWR}

Menurut Soemartojo et al. (2018), terdapat dua macam fungsi pembobot kernel, yaitu kernel spasial tetap (fixed kernel) dan kernel spasial adaptif (adaptive kernel). Berikut fungsi pembobot untuk fixed kernel dan adaptive kernel yaitu: 
a. Fixed Gaussian Kernel

$$
w_{j}\left(u_{i}, v_{i}\right)=\exp \left[-\frac{1}{2}\left(\frac{a_{i j}}{k_{h}}\right)^{2}\right]
$$

b. Fixed Bisquare Kernel

$$
w_{j}\left(u_{i}, v_{i}\right)=\left\{\left(1-\left(\frac{d_{i j}}{h}\right)^{2}\right)^{2}, \text { untuk } d_{i j} \leq h\right.
$$

c. Fixed Tricube Kernel

$$
w_{j}\left(u_{i}, v_{i}\right)=\left\{\left(\begin{array}{c}
\left(1-\left(\frac{d_{i j}}{h}\right)^{3}\right. \\
0
\end{array}\right)^{3}, \text { untuk } d_{i j} \leq h\right.
$$

d. Adaptive Gaussian Kernel

$$
w_{j}\left(u_{i}, v_{i}\right)=\exp \left[-\frac{1}{2}\left(\frac{\varpi_{i j}}{\tilde{k}_{i}}\right)^{2}\right]
$$

e. Adaptive Bisquare Kernel

$$
w_{j}\left(u_{i}, v_{i}\right)=\left\{\left(\begin{array}{c}
\left(1-\left(\frac{d_{i j}}{h_{i}}\right)^{2}\right. \\
0
\end{array}\right)^{2}, \text { untuk } d_{i j} \leq h_{i}\right.
$$

f. Adaptive Tricube Kernel

Keterangan:

$$
w_{j}\left(u_{i}, v_{i}\right)=\left\{\left(\begin{array}{c}
1-\left(\frac{d_{i j}}{h_{i}}\right)^{3} \\
0
\end{array}\right)^{3}, \text { untukd } d_{i j} \leq h_{i}\right.
$$

$i, j \quad: \quad 1,2, \ldots, n \quad ; n \neq j$

$d_{i j} \quad$ : Jarak Euclidean antara lokasi pengamatan $i$ dengan lokasi pengamatan $j$

$h_{i} \quad$ Nilai Bandwidth pada lokasi ke- $i$

Pendugaan Parameter Model GWR

Pendugaan parameter pada model Geographically Weighted Regression (GWR) dapat menggunakan metode Weighted Least Square (WLS) (Fotheringham et al., 2002). Pendugaan parameter model GWR untuk setiap wilayah yaitu:

$$
\widehat{\boldsymbol{\beta}}_{j}\left(u_{i}, v_{i}\right)=\left(\boldsymbol{X}^{s} \boldsymbol{W}\left(u_{i}, v_{i}\right) \boldsymbol{X}\right)^{-1} \boldsymbol{X}^{s} \boldsymbol{W}\left(u_{i}, v_{i}\right) \boldsymbol{Y}
$$

Keterangan:

$\boldsymbol{X} \quad$ : matriks berprediktor berdimensi $n \times(p+1)$

$\boldsymbol{Y} \quad:$ matriks respon berdimensi $n \times \mathbb{1}$

$\widehat{\boldsymbol{\beta}_{j}}\left(u_{i}, v_{i}\right) \quad:$ vektor penduga parameter GWR variabel prediktor ke-funtuk setiap wilayah ke- $\hat{i}$

$u_{i} \quad:$ koordinat spasial longitude untuk lokasi ke-i

$v_{i} \quad:$ koordinat spasial latitude untuk lokasi ke- $i$ 


\section{Uji Kesesuaian Model GWR}

Uji kesesuaian model (goodness of fit) dilakukan untuk menjelaskan apakah model GWR dapat menjelaskan lebih baik dibandingkan model regresi linier atau tidak (Damayanti, 2016).

$H_{0}: \beta_{1}\left(u_{i}, v_{i}\right)=\beta_{k}, k=1,2, \ldots, p, i=1,2, \ldots, n$

(tidak ada perbedaan signifikan antara model regresi global dan model GWR)

$H_{1}$ : minimal ada satu $\beta_{k}\left(u_{i}, v_{i}\right) \neq 0$

(ada perbedaan signifikan antara model regresi global dan model GWR)

Statistik uji yang digunakan:

$$
F^{*}=\frac{\operatorname{SSE}\left(H_{0}\right) / d f_{1}}{\operatorname{SSE}\left(H_{1}\right) / d f_{2}}
$$

Jika $F^{*}$ lebih besar dari $F_{\text {tabel }}$ maka dapat diambil keputusan tolak $H_{0}$, atau dapat dikatakan bahwa model GWR memiliki model yang lebih baik daripada model regresi global.

\section{Uji Signifikansi Parameter secara Parsial}

Pengujian parameter secara parsial memiliki tujuan untuk mengetahui parameter mana saja yang signifikan memengaruhi variabel responnya.

$H_{0}: \beta_{k}\left(u_{i}, v_{i}\right)=0$ (parameter tidak signifikan)

$H_{1}: \beta_{k}\left(u_{i}, v_{i}\right) \neq 0 ; k=1,2, \ldots, p$ (parameter signifikan)

Statistik uji yang digunakan adalah:

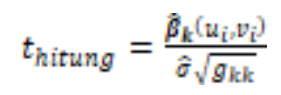

Jika $\left.\left|t_{\text {hitung }}\right|>t_{\frac{a}{2}} d f f\right)$, maka keputusan akan tolak $H_{0}$.

\section{Pemilihan Model Terbaik}

Pemilihan model terbaik pada model GWR dapat dilihat dari nilai Akaike Information Criterion (AIC). Model terbaik ditentukan berdasarkan nilai AIC yang paling minimum. Persamaan nilai AIC pada model GWR adalah sebagai berikut:

$$
A I C=2 n \log _{\Theta}(\hat{\sigma})+n \log _{\Theta}(2 \pi)+n\left\{\frac{n+\operatorname{tr}(S)}{n-2-\operatorname{tr}(S)}\right\}
$$

\section{HASIL DAN PEMBAHASAN}

\section{Analisis Deskriptif}

Analisis deskriptif digunakan untuk mengetahui gambaran secara umum kasus kematian ibu dan faktor-faktor yang diduga berpengaruh. Hasil analisis deskriptif disajikan pada TABEL 2.

TABEL 2. Hasil Analisis Statistika Deskriptif

\begin{tabular}{ccccc}
\hline Variabel & Nilai Minimum & Nilai Maksimum & Rata - rata & Ragam \\
\hline $\mathrm{Y}$ & 0 & 41 & 13.74 & 82.25 \\
$\mathrm{X}_{1}$ & 18.2 & 83.20 & 51.92 & 243.84 \\
$\mathrm{X}_{2}$ & 73.14 & 99.96 & 89.78 & 43.74 \\
$\mathrm{X}_{3}$ & 79.6 & 100 & 90.67 & 32.76 \\
$\mathrm{X}_{4}$ & 86.5 & 102.3 & 95.5 & 18.18 \\
$\mathrm{X}_{5}$ & 176 & 3241 & 1381.3 & 609781.9 \\
\hline
\end{tabular}

Banyaknya kasus kematian ibu (Y) dapat menggambarkan kesejahteraan suatu negara. Sebagian besar kabupaten/kota di Provinsi Jawa Timur memiliki kasus kematian ibu sebanyak 14 orang. 
Berdasarkan hasil analisis pada TABEL 2 dapat diketahui bahwa kasus kematian ibu tertinggi sebanyak 41 orang berada di Kabupaten Jembr. Sedangkan, kasus kematian ibu terendah sebesar 0 kasus berada di Kota Madiun dan Kota Batu. Keragaman jumlah kematian ibu di Jawa Timur yaitu sebesar 82.25. Rata-rata kasus kematian ibu di Provinsi Jawa Timur masih tergolong tinggi karena melebihi target dari Renstra, sehingga perlu dilakukan upaya penurunan kematian ibu melalui faktor-faktor yang diduga dapat mempengaruhinya.

\section{Analisis Regresi Linier Berganda}

Analisis regresi linier berganda digunakan untuk mengetahui besar pengaruh antara variabel bebas dan variabel terikat maka digunakan analisis regresi. TABEL 3 menyajikan hasil analisis regresi linier berganda.

\begin{tabular}{|c|c|c|}
\hline Variabel & Koefisien & p-value \\
\hline Konstanta & -4.414 & 0.8386 \\
\hline $\mathrm{X}_{1}$ & -0.036 & 0.5766 \\
\hline $\mathrm{X}_{2}$ & 0.242 & 0.3111 \\
\hline $\mathrm{X}_{3}$ & -0.58 & 0.0381 \\
\hline $\mathrm{X}_{4}$ & 0.408 & 0.1514 \\
\hline $\mathrm{X}_{5}$ & 0.009 & $6.70 \times 10^{-08}$ \\
\hline
\end{tabular}

Uji Simultan

Uji simultan dilakukan untuk mengetahui pengaruh beberapa variabel bebas secara bersama - sama terhadap suatu variabel terikat melalui Uji F. Hipotesis yang digunakan pada pengujian simultan yaitu sebagai berikut:

$$
\begin{aligned}
& H_{0}: \beta_{1}=\beta_{2}=\ldots=\beta_{p}=0 \\
& H_{1}: \beta_{j} \neq \beta_{2}, \operatorname{dimana} \mathrm{j}=1,2,3,4,5
\end{aligned}
$$

TABEL 4. Hasil Uji Simultan

\begin{tabular}{ccc}
\hline Statistik Uji & p-value & Keputusan \\
\hline 13.161 & $5.35 \times 10^{-07}$ & Tolak $H_{0}$ \\
\hline
\end{tabular}

Hasil uji simultan dengan Uji F yang disajikan pada TABEL 4, menunjukkan bahwa nilai $p$-value $<0.05$, yang artinya $\mathrm{H}_{0}$ ditolak. Hal ini menunjukkan bahwa persentase rumah tangga ber-PHBS, persentase ibu hamil mendapat tablet $\mathrm{Fe}$, persentase kunjungan ibu hamil dengan $\mathrm{K} 4$, persentase ibu yang proses persalinannya dibantu tenaga kesehatan dan jumlah fasilitas kesehatan secara bersama sama berpengaruh nyata terhadap jumlah kematian ibu.

\section{Uji Parsial}

Uji parsial dilakukan untuk mengetahui pengaruh masing - masing variabel bebas terhadap variabel terikat secara parsial melalui statistik Uji t. Hipotesis yang digunakan yaitu sebagai berikut:

$$
\begin{aligned}
& \mathrm{H}_{0}: \beta_{\mathrm{j}}=0 \\
& \mathrm{H}_{1}: \beta_{\mathrm{j}} \neq 0, \text { dimana } \mathrm{j}=1,2,3,4,5
\end{aligned}
$$

Berdasarkan TABEL 3 menunjukkan bahwa variabel $\mathrm{X}_{3}$ dan variabel $\mathrm{X}_{5}$ memiliki $p$-value $<0.05$. Hal ini menunjukkan bahwa variabel persentase kunjungan ibu hamil dengan K4 dan variabel jumlah fasilitas kesehatan berpengaruh terhadap jumlah kematian ibu secara parsial atau sendiri - sendiri. Sedangkan untuk variabel $\mathrm{X}_{1}, \mathrm{X}_{2}, \mathrm{X}_{4}$ memiliki $p$-value $>0.05$, yang artinya variabel persentase rumah tangga ber-PHBS, persentase ibu hamil mendapat tablet $\mathrm{Fe}$, persentase ibu yang proses persalinannya 
dibantu tenaga kesehatan tidak berpengaruh secara parsial atau sendiri - sendiri terhadap jumlah kematian ibu.

\section{Stasioneritas Data}

Geographically Weighted Regression (GWR) merupakan salah satu metode statistik yang mempertimbangkan unsur lokasi pada data tidak stasioner dan menggunakan pembobot lokasi dalam menaksir parameter (Irevanie, 2017). Maka dari itu, untuk mengetahui apakah data stasioner atau tidak dibentuk plot data yang disajikan pada GAMBAR 1.

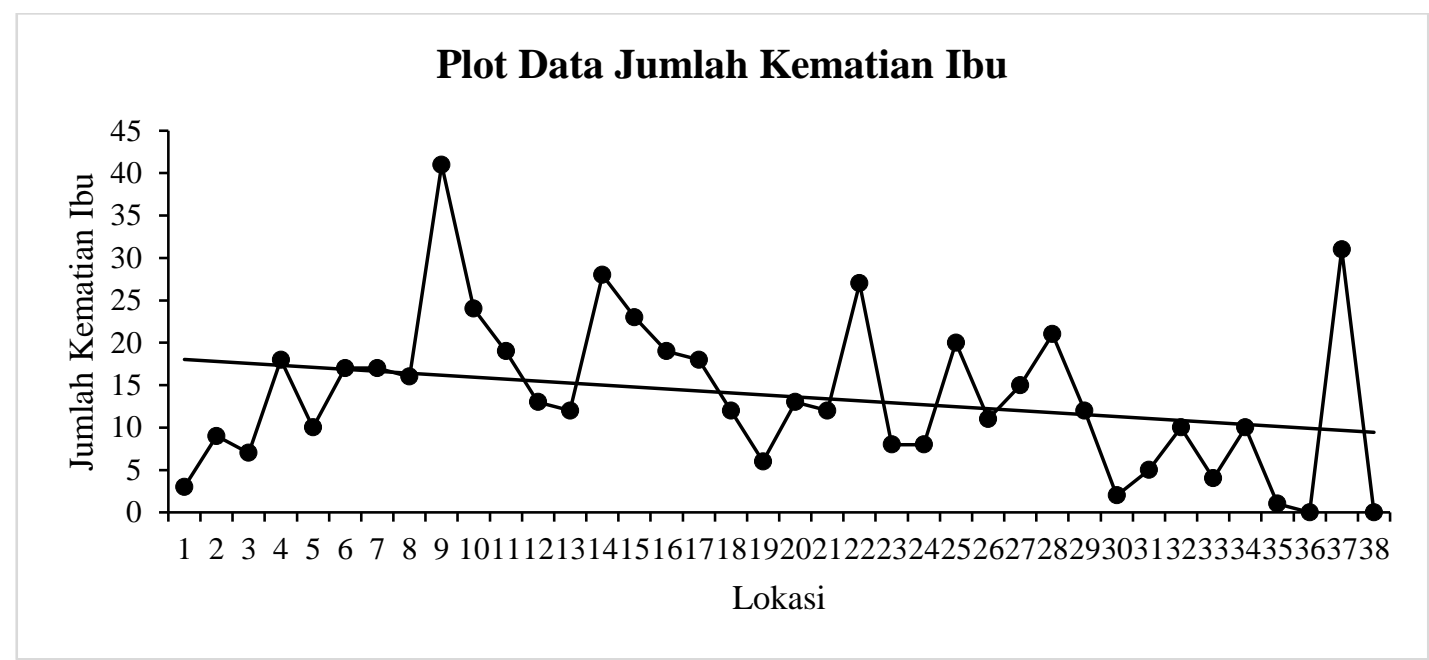

GAMBAR 1. Plot data jumlah kematian ibu

Hasil plot data pada GAMBAR 1 menunjukkan bahwa data memiliki kecenderungan trend menurun, sehingga plot data di atas tergolong non-stasioner. Pada data spasial yang tidak stasioner akan lebih tepat jika digunakan GWR daripada regresi linier berganda, karena GWR dapat menghasilkan parameter yang berbeda - beda di setiap lokasi.

\section{Pengujian Asumsi GWR}

Sebelum dilakukan pemodelan GWR perlu dilakukan pengujian asumsi GWR yang terdiri dari uji non-multikolinieritas dan uji heterogenitas spasial.

\section{Uji Non Multikolinieritas}

Pada TABEL 5 disajikan nilai VIF untuk masing-masing variabel prediktor.

\begin{tabular}{cc}
\multicolumn{2}{c}{ TABEL 5. Nilai VIF Variabel Prediktor } \\
\hline Variabel & VIF \\
\hline $\mathrm{X}_{1}$ & 1.182 \\
$\mathrm{X}_{2}$ & 2.866 \\
$\mathrm{X}_{3}$ & 2.804 \\
$\mathrm{X}_{4}$ & 1.663 \\
$\mathrm{X}_{5}$ & 1.131 \\
\hline
\end{tabular}

Berdasarkan hasil pengujian yang disajikan pada TABEL 5, didapatkan nilai VIF pada setiap variabel prediktor $<10$. Hal ini berarti tidak terjadi multikolinieritas pada data.

\section{Uji Heterogenitas Spasial}

Pada TABEL 6 berikut disajikan statistik uji Breusch-Pagan $(B P)$. 
TABEL 6. Hasil Uji Asumsi Heterogenitas

\begin{tabular}{lcc}
\hline \multicolumn{1}{c}{ Pembobot } & BP & p-value \\
\hline Adaptive Gaussian & 11.683 & 0.039 \\
Adaptive Bisquare & 11.772 & 0.038 \\
Adaptive Tricube & 11.728 & 0.039 \\
Fixed Gaussian & 11.683 & 0.039 \\
Fixed Bisquare & 11.693 & 0.039 \\
Fixed Tricube & 11.685 & 0.039 \\
\hline
\end{tabular}

Berdasarkan hasil pengujian asumsi heterogenitas spasial yang disajikan pada TABEL 6 menunjukkan bahwa $p$-value dari pembobot adaptif dan fixed $<\alpha(0.05)$ yang artinya tolak $H_{0}$, sehingga dapat disimpulkan bahwa terdapat heterogenitas spasial.

\section{Pemilihan Bandwidth Optimum}

Fungsi pembobot adaptive kernel memiliki nilai bandwidth yang berbeda untuk setiap wilayah pengamatan. Pada TABEL 7 disajikan bandwidth optimum menggunakan fungsi pembobot adaptive kernel.

TABEL 7. Bandwidth Adaptive Kernel

\begin{tabular}{lccc}
\hline \multirow{2}{*}{ Kota/Kabupaten } & \multicolumn{3}{c}{ Bandwidth Adaptive Kernel } \\
\cline { 2 - 4 } & Gaussian & Bisquare & Tricube \\
\hline Pacitan & 378597.4 & 378565.3 & 378543.8 \\
Ponorogo & 338234.0 & 338207.8 & 338190.2 \\
$\vdots$ & $\vdots$ & $\vdots$ & $\vdots$ \\
Batu & 228230.3 & 228205.2 & 228188.4 \\
\hline
\end{tabular}

Pada fungsi pembobot fixed kernel memiliki nilai bandwidth yang sama untuk seluruh wilayah penelitian. Pada TABEL 8 disajikan bandwidth optimum menggunakan fungsi pembobot fixed kernel.

\begin{tabular}{lr}
\multicolumn{2}{c}{ TABEL 8. Bandwidth Fixed Kernel } \\
\hline \multicolumn{1}{c}{ Fungsi Pembobot } & Bandwidth \\
\hline Fixed Kernel Gaussian & 391066.7 \\
Fixed Kernel Bisquare & 391066.7 \\
Fixed Kernel Tricube & 391066.7 \\
\hline
\end{tabular}

\section{Matriks Pembobot Spasial}

Setelah didapatkan nilai bandwidth yang optimum, dapat dibentuk matriks pembobot $\boldsymbol{W}\left(u_{i}, v_{i}\right)$ dengan mensubtitusikan bandwidth optimum dan jarak euclidean $\left(d_{i j}\right)$ ke persamaanfungsi pembobot. Berikut matriks pembobot untuk Kabupaten Jember.

a. Adaptive Gaussian Kernel

$W\left(u_{g}, v_{q}\right)=\operatorname{diag}[0,770803, \ldots, 0,846475]$

b. Adaptive Bisquare Kernel

$W\left(u_{g}, v_{q}\right)=\operatorname{diag}[0,229696, \ldots, 0,444325]$

c. Adaptive Tricube Kernel

$W\left(u_{g}, v_{9}\right)=\operatorname{diag}[0,243162, \ldots, 0,526398]$

d. Fixed Gaussian Kernel

$W\left(u_{g}, v_{q}\right)=\operatorname{diag}[0,783,0,828, \ldots, 0,945]$

e. Fixed Bisquare Kernel

$W\left(u_{g}, v_{g}\right)=\operatorname{diag}[0,262,0,388, \ldots, 0,786]$ 
f. Fixed Tricube Kernel $W\left(u_{g}, v_{9}\right)=\operatorname{diag}[0,64,0497, \ldots, 0,889]$

\section{Pendugaan Parameter Model GWR}

Setiap lokasi yang diteliti akan menghasilkan penduga parameter yang berbeda-beda, sehingga antar kota/kabupaten akan memiliki koefisien regresi yang berbeda.

TABEL 9. Pendugaan Parameter dengan Fungsi Pembobot Adaptive Gaussian Kernel

\begin{tabular}{|c|c|c|c|c|c|c|}
\hline Kabupaten/Kota & $\mathrm{P}_{0}$ & $\tilde{P}_{i}$ & $\hat{p}_{i}$ & $\hat{P}_{0}$ & $\mathrm{r}_{0}$ & $p_{m}$ \\
\hline Pacitan & -7.1103 & -0.0327 & 0.1966 & -0.5529 & 0.4507 & 0.0086 \\
\hline Ponorogo & -7.0608 & -0.0328 & 0.1955 & -0.5503 & 0.4489 & 0.0086 \\
\hline Batu & $\begin{array}{c}\vdots \\
-5.5957\end{array}$ & $\begin{array}{c}\vdots \\
-0.0274\end{array}$ & 0.2183 & $\begin{array}{c}\vdots \\
-0.5626\end{array}$ & 0.4223 & 0.0086 \\
\hline
\end{tabular}

TABEL 10. Pendugaan Parameter dengan Fungsi Pembobot Adaptive Bisquare Kernel

\begin{tabular}{|c|c|c|c|c|c|c|}
\hline Kabupaten/Kota & $\mathrm{P}_{0}$ & $\tilde{p}_{i}$ & $\mathrm{e}_{\bar{L}}$ & $\mathrm{P}_{\mathrm{u}}$ & $\tilde{P}_{2}$ & 笊 \\
\hline Pacitan & -15.7999 & -0.0308 & 0.0314 & -0.4409 & 0.5926 & 0.0083 \\
\hline Ponorogo & -15.0810 & -0.0316 & 0.0331 & -0.4298 & 0.5734 & 0.0083 \\
\hline$\vdots$ & & $\vdots$ & $\vdots$ & & & \\
\hline Batu & -7.7875 & -0.0050 & 0.1180 & -0.4601 & 0.4358 & 0.0082 \\
\hline
\end{tabular}

TABEL 11. Pendugaan Parameter dengan Fungsi Pembobot Adaptive Tricube Kernel

\begin{tabular}{|c|c|c|c|c|c|c|}
\hline Kabupaten/Kota & $p_{0}$ & 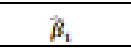 & $p_{2}$ & 管 & $B_{3}$ & P. \\
\hline Pacitan & -14.4359 & -0.0303 & 0.0297 & -0.4328 & 0.5727 & 0.0082 \\
\hline Ponorogo & -13.6922 & -0.0301 & 0.0376 & -0.4242 & 0.5491 & 0.0083 \\
\hline & : & & $\vdots$ & : & : & : \\
\hline Batu & -7.3602 & -0.0086 & 0.1349 & -0.4743 & 0.4294 & 0.0083 \\
\hline
\end{tabular}

TABEL 12. Pendugaan Parameter dengan Fungsi Pembobot Fixed Gaussian Kernel

\begin{tabular}{|c|c|c|c|c|c|c|}
\hline Kabupaten/Kota & $\widehat{\beta}_{0}$ & $\widehat{\beta}_{1}$ & $\widehat{\boldsymbol{\beta}}_{2}$ & $\widehat{\boldsymbol{\beta}}_{3}$ & $\widehat{\boldsymbol{\beta}}_{4}$ & $\widehat{\boldsymbol{\beta}}_{5}$ \\
\hline Pacitan & -6.9503 & -0.0329 & 0.1993 & -0.5546 & 0.4481 & 0.0086 \\
\hline Ponorogo & -6.4284 & -0.0334 & 0.2067 & -0.5578 & 0.439 & 0.0087 \\
\hline$\vdots$ & $\vdots$ & $\vdots$ & $\vdots$ & $\vdots$ & $\vdots$ & $\vdots$ \\
\hline Batu & -4.8596 & -0.0329 & 0.2336 & -0.5747 & 0.4133 & 0.0087 \\
\hline
\end{tabular}

TABEL 13. Pendugaan Parameter dengan Fungsi Pembobot Fixed Bisquare Kernel

\begin{tabular}{|c|c|c|c|c|c|c|}
\hline Kabupaten/Kota & $\widehat{\beta}_{0}$ & $\widehat{\beta}_{1}$ & $\widehat{\boldsymbol{\beta}}_{2}$ & $\widehat{\boldsymbol{\beta}}_{3}$ & $\widehat{\boldsymbol{\beta}}_{4}$ & $\widehat{\boldsymbol{\beta}}_{5}$ \\
\hline Pacitan & -15.2826 & -0.0296 & 0.0438 & -0.4509 & 0.5841 & 0.0086 \\
\hline Ponorogo & -12.9768 & -0.0285 & 0.0838 & -0.4722 & 0.5413 & 0.0087 \\
\hline$\vdots$ & $\vdots$ & $\vdots$ & $\vdots$ & $\vdots$ & $\vdots$ & $\vdots$ \\
\hline Batu & -6.287 & -0.0231 & 0.2054 & -0.5532 & 0.4311 & 0.0083 \\
\hline
\end{tabular}

TABEL 14. Pendugaan Parameter dengan Fungsi Pembobot Fixed Tricube Kernel

\begin{tabular}{lcccccc}
\hline Kabupaten/Kota & $\widehat{\boldsymbol{\beta}}_{\mathbf{0}}$ & $\widehat{\boldsymbol{\beta}}_{\mathbf{1}}$ & $\widehat{\boldsymbol{\beta}}_{\mathbf{2}}$ & $\widehat{\boldsymbol{\beta}}_{\mathbf{3}}$ & $\widehat{\boldsymbol{\beta}}_{\mathbf{4}}$ & $\widehat{\boldsymbol{\beta}}_{\mathbf{5}}$ \\
\hline Pacitan & -14.4359 & -0.0303 & 0.0297 & -0.4328 & 0.5727 & 0.0086 \\
Ponorogo & -13.6922 & -0.0301 & 0.0376 & -0.4242 & 0.5491 & 0.0087 \\
\multicolumn{1}{c}{$\vdots$} & $\vdots$ & $\vdots$ & $\vdots$ & $\vdots$ & $\vdots$ & $\vdots$ \\
Batu & -7.3602 & -0.0086 & 0.1348 & -0.4743 & 0.4294 & 0.0083 \\
\hline
\end{tabular}

\section{Pengujian Parameter Model GWR Secara Simultan}

Berdasarkan hasil pengujian menggunakan statistik Uji F, diperoleh hasil bahwa terdapat perbedaan 
antara model regresi linier berganda dengan model GWR fungsi pembobot adaptive kernel dan fixed kernel. Hal itu menunjukkan bahwa model GWR menggunakan fungsi pembobot adaptive kernel dan fixed kernel memiliki goodness of fit yang lebih baik dibandingkan model regresi global.

\section{Pengujian Signifikansi Parameter Model GWR}

Hasil pengujian signifikansi parameter model GWR menunjukkan bahwa variabel persentase kunjungan ibu hamil dengan K4 berpengaruh signifikan terhadap kematian ibu di beberapa kabupaten di Jawa Timur. Sedangkan, variabel jumlah fasilitas kesehatan berpengaruh terhadap kematian ibu di seluruh kabupaten/kota di Jawa Timur.

\section{Pemilihan Model Terbaik}

Penentuan model GWR terbaik dengan fungsi pembobot yang berbeda dapat dilihat melalui nilai AIC yang terkecil. Berdasarkan hasil penghitungan, model GWR dengan fungsi pembobot Adaptive Bisquare Kernel memiliki nilai AIC terkecil. Dengan demikian, model GWR dengan fungsi pembobot Adaptive Bisquare Kernel lebih baik dibandingkan fungsi pembobot Adaptive Gaussian Kernel, Adaptive Tricube Kernel, Fixed Gaussian Kernel, Fixed Bisquare Kernel dan Fixed Tricube Kernel untuk memodelkan data kematian ibu di Jawa Timur tahun 2018.

\section{Model GWR dengan Pembobot Adaptive Bisquare Kernel}

Berikut ini merupakan model GWR dengan fungsi pembobot Adaptive Bisquare Kernel di Kabupaten Jember.

$$
\hat{y}=-1.9159+0.0377 X_{1}+0.5291 X_{2}-0.8075 X_{3}+0.3055 X_{4}+0.0079 X_{5}
$$

Persamaan tersebut menjelaskan bahwa kenaikan persentase kunjungan ibu hamil dengan K4 sebesar $1 \%$ akan menurunkan kasus kematian ibu di Kabupaten Jember sebesar $0.8075 \%$ dengan variabel lainnya dianggap konstan serta dipengaruhi oleh wilayah yang berdekatan. Sedangkan kenaikan jumlah fasilitas kesehatan sebesar 1\% akan meningkatkan kasus kematian ibu di Kabupaten Jember sebesar 0.0079\% dengan variabel lainnya dianggap konstan serta dipengaruhi oleh wilayah yang berdekatan.

\section{KESIMPULAN DAN SARAN}

Berdasarkan hasil analisis yang telah dilakukan dapat diambil kesimpulan bahwa pemodelan GWR dengan fungsi pembobot adaptive bisquare kernel merupakan model terbaik untuk data kematian ibu di Jawa Timur tahun 2018 berdasarkan kriteria nilai AIC terkecil. Faktor yang mempengaruhi kasus kematian ibu di Provinsi Jawa Timur berdasarkan pengujian parameter secara parsial yaitu kunjungan ibu hamil dengan K4 dan jumlah fasilitas kesehatan. Model GWR dengan fungsi pembobot adaptive bisquare kernel untuk kasus kemtian Ibu di Jawa Timur 2018 juga menunjukkan bahwa variabel yang berpengaruh secara global adalah fasilitas kesehatan dan variabel yang berpengaruh secara lokal adalah kunjungan ibu hamil dengan K4.

\section{UCAPAN TERIMA KASIH}

Penulis mengucapkan terima kasih kepada Dinas Kesehatan Provinsi Jawa Timur yang telah menyediakan data untuk penelitian ini.

\section{REFERENSI}

Anselin, L 1988, 'Spatial Econometrics: Methods and Models' London: Kluwer Academic Publishers. Anselin, L. dan Getis, A 1992, 'Spatial statistical analysis and geographic information systems' The

Annals of Regional Science, 26(1), 19-33. 
Caraka, R. E., dan Yasin, H 2017, ‘Geographically Weighted Regression (GWR) Sebuah Pendekatan Regresi Geografis’. Yogyakarta: Mobius.

Charlton, M., Fotheringham, S., dan Brunsdon, C 2009, 'Geographically weighted regression' White paper, National Centre for Geocomputation, National University of Ireland Maynooth.

Dinas Kesehatan Jawa Timur 2018, 'Profil Kesehatan Provinsi Jawa Timur Tahun 2018' Surabaya: Dinas Kesehatan Jawa Timur.

Fotheringham, A. S., Brunsdon, C., dan Charlton, M. E 2002, 'Geographically Weighted Regression: The Analysis of Spatially Varying Relationships'. Chichester: John Wiley \& Sons,Inc.

Gujarati, D. N. 2004. Basic Econometrics Fourth Edition. Boston: McGraw-Hill.

Irevanie, R. S 2017, 'Perbandingan Metode Quantile Regression (QR) dan Geographically Weighted Regression (GWR) Pada Data Angka Harapan Hidup di Indonesia' Doctoral dissertation. Surabaya: Institut Teknologi Sepuluh Nopember.

Kementerian Kesehatan 2014, 'Situasi Kesehatan Ibu' Diakses pada 11 Desember 2020. https://www.kemkes.go.id/article/view/15021800009/situasi-kesehatan-ibu.html.

Munikah, T., Pramoedyo, H., dan Fitriani, R 2014, 'Pemodelan Geographically Weighted Regression dengan Pembobot Fixed Gaussian Kernel pada Data Spasial (Studi Kasus Ketahanan Pangan di Kabupaten Tanah Laut Kalimantan Selatan)' Natural B, 2 (3), 296-302.

Soemartojo, S. M., Ghaisani, R. D., Siswantining, T., Shahab, M. R., dan Ariyanto, M. M 2018, 'Parameter estimation of geographically weighted regression (GWR) model using weighted least square and its application'. In AIP Conference Proceedings Vol. 2014, No. 1, p. 020081 AIP Publishing LLC. 